\title{
The Design of an Instructional Model Based on Connectivism and Constructivism to Create Innovation in Real World Experience
}

\author{
Kanokrat Jirasatjanukul ${ }^{1}$ \& Namon Jeerungsuwan ${ }^{2}$ \\ ${ }^{1}$ Faculty of Science and Technology, Phetchaburi Ratjabhat University, Thailand \\ ${ }^{2}$ Faculty of Technical Education, King Mongkut's University of Technology North Bangkok, Thailand \\ Correspondence: Kanokrat Jirasatjanukul, Faculty of Science and Technology, Phetchaburi Ratjabhat University, \\ Phetchabuir 76000, Thailand. Tel: 6-686-305-5333. E-mail: kanokrat.jir@mail.pbru.ac.th
}

\author{
Received: October 1, $2017 \quad$ Accepted: November 5, $2017 \quad$ Online Published: February 25, 2018 \\ doi:10.5539/ies.v11n3p12 URL: https://doi.org/10.5539/ies.v11n3p12
}

\begin{abstract}
The objectives of the research were to (1) design an instructional model based on Connectivism and Constructivism to create innovation in real world experience, (2) assess the model designed-the designed instructional model. The research involved 2 stages: (1) the instructional model design and (2) the instructional model rating. The sample consisted of 7 experts, and the Purposive Sampling Technique was used. The research instruments were the instructional model and the instructional model evaluation form. The statistics used in the research were means and standard division. The research results were (1) the Instructional Model based on Connectivism and Constructivism to Create innovation in Real World Experience consisted of 3 components. These were Connectivism, Constructivism and Innovation in Real World Experience and (2) the instructional model rating was at a high level $(\bar{X}=4.37$, S.D. $=0.41)$. The research results revealed that the Instructional Model Based on Connectivism and Constructivism to Create Innovation in Real World Experience was a model that can be used in learning, in that it promoted the creation of real world experience innovation.
\end{abstract}

Keywords: Thailand 4.0, Connectivism, Constructivism, innovation in the real world

\section{Introduction}

Social and economic change throughout the world aims to develop the lives of the population in the various countries. This development is the reason for the reform of the world's industry with regard to the Industry 4.0 era (Bureau of Academic Services of the Secretariat of the House of Representatives, 2016). Industry 4.0 is becoming increasingly successful, especially in Europe (Schmidt et al, 2015). To enable Thailand to be a competitive country internationally, it is necessary to develop the industrial sector in line with Industry 4.0. This is the background of the Thailand 4.0 Model (Bureau of Academic Services of the Secretariat of the House of Representatives, 2016). Thailand 4.0 is the approach that is being used to driving Thailand's economic reform. It focuses on building wealth in 21 st Century using innovation (Suwit, 2016). To ensure such change, education becomes an important tool when it comes to raising the quality of the country's population (Kieatinan, 2016)

Education is the root of driving the nation towards Thailand 4.0 (Paitoon, 2015). Every level of learners has to be developed to become ready, and to be able to encourage innovation. In other words, all learners have the capability and skill to create innovation.

Learning takes place both inside and outside each learner (Namon, 2015). This is the background of Connectivism. Connectivism is a learning theory associated with the digital era (Siemens, 2005). Nowadays, learning is connected to the outside through the Internet. Learners construct their own knowledge by connecting to the resources they need, and managing the relationship associated with knowledge connection. Learning occurs as part of a process by which learners connect data and input (Kop \& Hill, 2008). Moreover, Connectivism promotes learning in the 21 st Century by placing emphasis on the learner's ability to communicate and cooperate (Wijarn, 2012). However, in the real world working situation, learners are unable to apply classroom knowledge. The Real World Problem Learning Experience helps build a strong connection. This learning model enables learners to apply what they have learned to real life situations (Amara, 2013). Constructivism is the basis of knowledge construction theory. The learning environment based on the theory promotes the context of real life situations and develops the skill associated with innovation creation. 
In order to develop innovation creation skills and the knowledge application ability for the learners' future occupations, the researchers designed an Instructional Model based on Connectivism and Constructivism to Create Innovation in Real World Experience.

\section{Objectives of the Research}

1) To design an Instructional Model based on Connectivism and Constructivism to Create Innovation in Real World Experience.

2) To rate the Instructional Model based on Connectivism and Constructivism to Create Innovation in Real World Experience.

\section{Scope of the Research}

\subsection{Population and Sample}

The population consisted of instructional design experts and teaching experts. The samples consisted of 7 experts using the Purposive Sampling Technique.

\subsection{Variables}

The independent variable is the Instructional Model based on Connectivism and Constructivism to Create Innovation in Real World Experience.

The dependent variable is the suitability of the Instructional Model based on Connectivism and Constructivism to Create Innovation in Real World Experience.

\section{Methodology}

The Instructional Model based on Connectivism and Constructivism to Create Innovation in Real World Experience consisted of 2 stages:

Stage 1 Instructional Model Design

1) Review literatures and research associated with Thailand 4.0, Connectivism, Constructivism, 21st Century skills and skills of innovation creation. The researchers then analyzed the information and synthesized the concept frame of the instructional model.

2) Design an Instructional Model based on Connectivism and Constructivism for Creation of Innovation in Real World Experience. The design consisted of 3 components: 1) Connectivism: learning aim setting stage. Problems and conditions for coordination with any related agencies were provided in order to create task for the real world of work. 2) Constructivism: development stage. Learners connect their existing knowledge with new information. Learners construct new knowledge through communication and practice. 3) Innovation in the Real World: This involves the learning product.

3) Design teaching and learning activities based on the AAA Model process (Namon, 2007). The design consists of Analysis, Activities and Assessment.

4) Create a rating tool for the Instructional Model based on Connectivism and Constructivism to Create Innovation in Real World Experience.

\section{Stage 2 Instructional Model rating}

5) Present the developed instructional model and rating tool to 5 experts.

This involved the rating of the concordance of questions, the instructional model and the learning objectives.

6) Revise the instructional model based on the experts' suggestions.

7) Present the revised instructional model to 7 experts. The experts examined the model's suitability using a 5-point Likert Rating Scale (Likert, 1967).

8) Analyze the model rating results using means $(\bar{x})$ and standard deviation (S.D.).

\section{Research Results}

The results of the research in terms of its objectives are:

5.1 To Design an Instructional Model Based on Connectivism and Constructivism to Create Innovation in Real World Experience

The design of the Instructional Model based on Connectivism and Constructivism to Create Innovation in Real World Experience aimed to decrease learners' problems with regard to applying knowledge to the real world work situation, to promote learners' innovation creation skills and to respond to the economic policy driving towards the 
implementation of Thailand 4.0 by using innovation. The Model consisted of 3 components:

1) Connectivism: learning aim setting. The learning aim was set by the teacher. This consisted of providing problems with condition for connection with related agencies. This led to the creation of a real world task.

2) Constructivism: development stage. Learners integrated and connected their existing knowledge with new information. They created knowledge through communication and practice.

3) Innovation in the Real World: learning product. The model developed was entitled the "C2I Model", as shown in Figure 1.

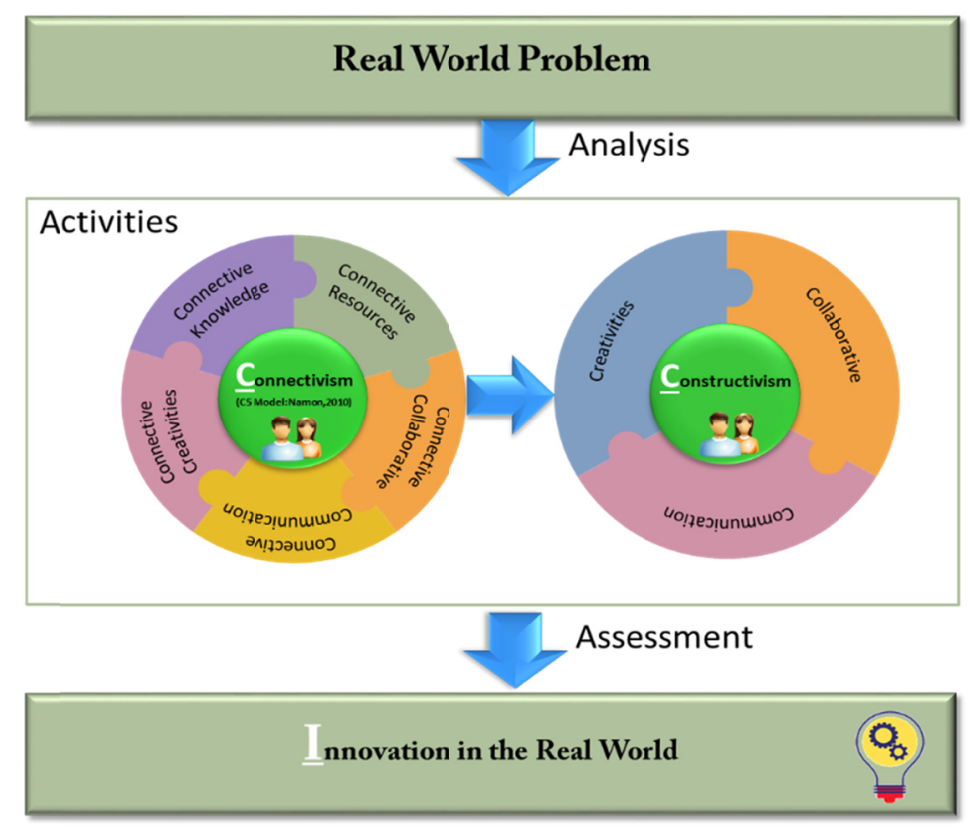

Figure 1. The C2I model

Learning activities stages of the instructional model:

1) Analysis. This involved context analysis including subject content analysis, learner analysis, person, community, company, related agencies' analysis and time analysis.

2) Activities. This component consisted of the aim and development stages:

2.1) Learning aim setting: teacher provided problem which conforms to the subject content. Learners were assigned to communicate with related agencies for the creation of a real world work task. The stage consisted of:

a) Connective Knowledge: teacher provided subject content, persons, community or related agencies.to support the learning.

b) Connective Resources: teacher provided the real world resources for the learning activities

c) Connective Collaboration: learners solved problems and learned cooperatively. They brainstormed the problem and presented their results within the group or to different groups, to people in the community or related agencies.

d) Connective Communication: learners developed their communication skills based on activities 2 and 3 .

e) Connective creativities: learners arrived at conclusions or crystallized their knowledge from each group's results.

2.2) Learner development: the learners integrated and connected their existing knowledge with new information by practicing. The development stage consisted of 3 components. Creativity: the learners created new knowledge. Collaboration: the learners built their concepts from sharing a variety of concepts within groups or between groups. Communication: learners connected and communicated with persons, the community or agencies. The process of development was: 
a) Development: the development followed the principle of the subject content development process.

b) Presentation: the learners presented their work. Each member shared ideas in his own group and between groups. The teacher made suggestions.

c) Revision: learners revised their work based on the teacher's suggestions.

d) Examination: agencies contacted in the first stage examined and evaluated the outcomes of the task.

e) Conclusion: teacher and learners collaboratively discussed and summarized the learning results.

3) Assessment: assessment consisted of determining the extent to which the innovation could be applied, the development of innovation creation skill and the development of occupational and learning skills.

\subsection{To Rate the Instructional Model Based on Connectivism and Constructivism to Create Innovation in Real World Experience}

The result of the C2I Model rating by 7 experts can be seen in Table 1 .

Table 1. The rating results with regard to the C2I Model

\begin{tabular}{|c|c|c|c|}
\hline Description & $\bar{X}$ & S.D. & Suitability \\
\hline $\begin{array}{l}\text { 1. Principles and concepts used in the design of the Instructional Model Based on Connectivism and } \\
\text { Constructivism to Create Innovation in Real World Experience. }\end{array}$ & 4.38 & 0.45 & $\begin{array}{l}\text { highly } \\
\text { suitable }\end{array}$ \\
\hline $\begin{array}{l}\text { 2. The objectives of the Design of Instructional Model Based on Connectivism and Constructivism to Create } \\
\text { Innovation in Real World Experience. }\end{array}$ & 4.40 & 0.49 & $\begin{array}{l}\text { highly } \\
\text { suitable }\end{array}$ \\
\hline $\begin{array}{l}\text { 3. Instructional Model Based on Connectivism and Constructivism to Create Innovation in Real World } \\
\text { Experience. }\end{array}$ & 4.35 & 0.41 & $\begin{array}{c}\text { highly } \\
\text { suitable }\end{array}$ \\
\hline Overall evaluation & 4.37 & 0.41 & $\begin{array}{c}\text { highly } \\
\text { suitable }\end{array}$ \\
\hline
\end{tabular}

Table 1 shows that the suitability of the C2I Model was at a high level $(\bar{X}=4.37$, S.D. $=0.41)$. The mean with regard to the model's objectives was the highest at 4.40 which indicates that the model was highly suitable.

Table 2. The result of C2I Model in terms of learning activities ratings

\begin{tabular}{|c|c|c|c|}
\hline Process & $\bar{X}$ & S.D. & Suitability \\
\hline \multicolumn{4}{|l|}{ 1. Analysis } \\
\hline Subject content analysis & 4.57 & 0.49 & very high \\
\hline Learner analysis & 4.43 & 0.49 & high \\
\hline Person, community or related agencies & 4.14 & 0.35 & high \\
\hline - $\quad$ Time analysis & 4.14 & 0.35 & high \\
\hline \multicolumn{4}{|l|}{ 2. Learning activities } \\
\hline \multicolumn{4}{|l|}{2.1 Goal setting } \\
\hline Connective Knowledge & 4.29 & 0.45 & high \\
\hline Connective Resources & 4.29 & 0.45 & high \\
\hline Connective Collaboration & 4.29 & 0.45 & high \\
\hline Connective Communication & 4.43 & 0.49 & high \\
\hline Connective Creativities & 4.29 & 0.45 & high \\
\hline \multicolumn{4}{|l|}{ 2.2 Development } \\
\hline Development & 4.43 & 0.49 & high \\
\hline Presentation & 4.57 & 0.49 & high \\
\hline Revision & 4.43 & 0.49 & high \\
\hline Examination & 4.29 & 0.45 & high \\
\hline Conclusion & 4.57 & 0.49 & very high \\
\hline \multicolumn{4}{|l|}{ 3. Assessment } \\
\hline - Applicable innovation & 4.57 & 0.49 & very high \\
\hline Innovation creation skill & 4.43 & 0.49 & high \\
\hline - $\quad$ Occupation and learning skill & 4.29 & 0.45 & high \\
\hline Overall Rating & 4.38 & 0.31 & high \\
\hline
\end{tabular}


Table 2 shows that the overall suitability of the learning activity was at a high level $(\bar{X}=4.38$, S.D. $=0.31)$ At the analysis stage, the suitability of the subject content was at a high level $(\bar{X}=4.57$, S.D. $=0.49)$ In terms of learning activities, the goal setting stage, and connective communication each was rated at a high level $(\bar{x}=$ 4.43, S.D. $=0.49)$. The development stage and presentation suitability were rated as being at a very high level $(\bar{X}$ $=4.57$, S.D. $=0.4)$. Conclusion suitability was at a very high level $(\bar{X}=4.57$, S.D. $=0.4)$. The assessment stage, and the suitability of applicable innovation was at a very high level $(\bar{X}=4.57$, S.D. $=0.49)$.

\section{Conclusion and Discussion}

The design of Instructional Model Based on Connectivism and Constructivism to Create Innovation in Real World Experience, the C2I Model, consisted of 3 components. These were 1) Connectivism 2) Constructivism and 3) Innovation in the Real World. Connectivism was the stage involved the setting of the learning aims. Problem with condition was provided in order to connect the students to related agencies and to create an appropriate task. Constructivism was the development stage. The learners integrated and connected their existing knowledge with new information. New knowledge was generated through communication and practice. Innovation in the Real World was the learning product.

The rating results of the suitability of the learning model rating based on the assessment of the experts showed that, overall, the suitability of the model was at a high level. The suitability of the learning activity stages was also at a high level. The results revealed that the C2I Model was suitable for teaching and learning. The research findings also support Ittipongse's research (2013). This research was based on constructivism theory. It helped to manage learning environments in the real world, and decrease the problems faced by learners in applying their learning to real world problems. The rating results in terms of applicable innovation were at the highest level. The finding revealed that the C2I Model promoted the creation of learner innovation skills, and the development of learning skills in the 21st Century (Wijarn, 2012), and it responded Thailand 4.0 development focusing on economy innovation driving (Sivit, 2016).

\section{References}

Bureau of Academic Services of the Secretariat of the House of Representatives. (2016). Thailand4.0. Retrieved from http://www.parliament.go.th/library

Ittipongse, A. (2013). Influencing of Cyber Lab to Conceptual Change through Laboratory's Learning: Case Study of Undergrad Students Who enrolling Fundamental Physics' Laboratory Subject, Faculty of Science and Technology Suansunandha University. Research of Suansunandha University, Faculty of Science and Technology.

Jeerungsuwan, N. (2007). Development of AAA Model for Blended Learning based on the Philosophy of Sufficiency Economy. Major: King Mongkut's University of Technology North Bangkok.

Jeerungsuwan, N. (2015). Design and evaluation. Bangkok: KMUTNB Textbook Publishing Center.

Kop, R., \& Hill, A. (2008). Connectivism: Learning theory of the future or vestige of the past? The International Review of Research in Open and Distributed Learning, 9(3). https://doi.org/10.19173/irrodl.v9i3.523

Likert, R. (1967). The Method of Constructing and Attitude Scale. In M. Fishbeic (Ed.), Reading in Attitude Theory and Measurement (pp. 90-95). New York: Wiley \& Son.

Luankaew, K. (2016). When Thailand 4.0 is powered by Education2.0. Newsletter, SanPanya Provinial Lerning reform (Vol. 26).

Mesintree, S. (2016). Conceptual Thailand 4.0. Retrieved from http://planning2.mju.ac.th/goverment/ 20111119104835_planning/Doc_25590823143652_358135.pdf

Panich, W. (2012). Learning Method for the students in 21st century. Bangkok: Tatha Publication Co.ltd

Parnership for 21st century skills. (2009). Framework for 21st Century Learning. Retrieved from http://www.p21.org

Schmidt, R., Möhring, M., Härting, R. C., Reichstein, C., Neumaier, P., \& Jozinović, P. (2015, June). Industry 4.0-potentials for creating smart products: Empirical research results. In International Conference on Business Information Systems (pp. 16-27). Springer, Cham. https://doi.org/10.1007/978-3-319-19027-3_2

Siemens, G. (2005).Connectivism: A learning theory for the digital age. International of Instructional Technology and Distance Learning, 2(1).

Sinlarat, P. (2015). Educational philosophy and creative productivity. Chulabook. Bangkok. 


\section{Copyrights}

Copyright for this article is retained by the author(s), with first publication rights granted to the journal.

This is an open-access article distributed under the terms and conditions of the Creative Commons Attribution license (http://creativecommons.org/licenses/by/4.0/). 